\title{
Quality Perception of Gen Z Consumer on Traditional Banking Services
}

\author{
Suemi Lima-Vargas ${ }^{1 *}$, Fernando Javier Cervantes-Aldana ${ }^{2}$, Alvaro Enrique Lima-Vargas ${ }^{3}$ \\ ${ }^{1}$ Tlalnepantla Professional Academic Unit, Autonomous University of the State of Mexico, Tlalnepantla, Mexico \\ ${ }^{2}$ Faculty of Accounting and Administration, National Autonomous University of Mexico, Coyoacan, Mexico \\ ${ }^{3}$ Playa del Carmen Campus, University of Quintana Roo, Playa del Carmen, Mexico \\ Email: *slimav@uaemex.mx
}

How to cite this paper: Lima-Vargas, S., Cervantes-Aldana, F. J., \& Lima-Vargas, A. E. (2021). Quality Perception of Gen Z Consumer on Traditional Banking Services. Open Journal of Business and Management, 9, 2548-2565.

https://doi.org/10.4236/ojbm.2021.95140

Received: July 8, 2021

Accepted: September 25, 2021

Published: September 28, 2021

Copyright (c) 2021 by author(s) and Scientific Research Publishing Inc. This work is licensed under the Creative Commons Attribution International License (CC BY 4.0).

http://creativecommons.org/licenses/by/4.0/

\begin{abstract}
In developing countries, digital banking has been introduced and, although it has grown tremendously, it still coexists with traditional banking, with branch service. The objective of this study is to explore the elements in the quality perception of Generation $\mathrm{Z}$ that makes them prefer traditional banking to digital banking in the context of a developing country, Mexico. The study of quality perception is implemented through the application of the SERVQUAL model with 22 items. There were applied 394 online surveys to users of traditional or digital banking from generation Z. Qualitative content analysis is used to understand the customer's quality perception of traditional banking, in which the variables considered were: tangibility, reliability, responsiveness, assurance, and empathy, which were evaluated through a 7-point Likert-type satisfaction survey $(1=$ Completely disagree, $7=$ Completely agree $)$. In this study, it was identified that the responsiveness variable which considers the attitudinal aspects of the branch staff and communication with the staff in traditional banking services, is the one that has the greatest impact on generation $\mathrm{Z}$ consumers, regardless of their socioeconomic status, and therefore, explaining the preference for traditional banking services over digital ones. In addition, from favoring traditional services, Generation $\mathrm{Z}$ users have evolved from a product perspective to a service perspective, where the aspects of tangibility and reliability take the background, giving greater relevance to responsiveness, assurance, and empathy which are focused on the employeeconsumer internment. This study offers a strategic starting point that will facilitate the banking sector to plan the development of strategies that stimulate the migration of banking services to digital banking services.
\end{abstract}

\section{Keywords}

SERVQUAL, Quality Perception, Generation Z, Bank 


\section{Introduction}

Economic development of countries is closely related to their financial system. A stable financial system will promote job development and improve investors' confidence in national markets, easing tax collection for the government, providing solidity, and consequently supporting infrastructure projects such as hospitals, highways, among others (World Bank, 2020).

In the case of the Mexican financial system, the economic crises that began with 1994's devaluation have generated major changes in the financial system during the last two decades. The main was the restructuring of the system, causing the privatization of banks, the internationalization of financial markets and the decline of the sector as a source of financing for the private sector (Villafani-Ibarnegaray \& González, 2006).

These changes have hampered the solidity of Mexican financial system, especially in the banking sector. This is the reason why banks have focused on market niches that they previously did not consider relevant (consumer). In this case, they have had to develop a new offer of products and services by virtue of their needs (Villafani-Ibarnegaray \& González, 2006).

On the other hand, the development of products and/or services in the banking sector can be considered since the integration of technology. The evolution began in the sixties culminating in the nineties with modern banking (Casilda, 1997), understanding modern banking as the integration of digital and traditional banking services.

During the sixties, banks focused on cost reduction, encountering various limitations in the transmission of information and staff training. In the 1970s, the objective of banks was modified, focusing on providing better customer service. Meanwhile, the integration of telecommunications in the banking sector began. This decade was characterized by the incorporation of services, such as the automatic teller machine (ATM) (Casilda, 1997).

The eighties are distinguished by the proliferation of bank branches. Finally, the nineties were differentiated by the development of digital banking, causing bank's decentralization of functions, allowing people to carry out operations remotely through digital banking (Casilda, 1997).

During the 21st century, the banking sector has increased its offer of products and/or services through the integration of technologies. As a result, traditional and digital banking services coexist within banking services today. Consequently, during the next few years, digital banking services will predominate in the banking sector. It is noteworthy that traditional banking services as any other service require the physical presence of the consumer or user and a bank employee in a bank branch.

However, several authors question the benefits of transferring services to a predominantly digital modality. Among the most relevant arguments are the influence of personal contact as a competitive advantage, the waste of a corporate image built over the years, the development of trust and image through tangible 
aspects, among many others (Márquez, 2000; Rexha et al., 2003; Torres \& Vásquez-Párraga, 2005).

Particularly, in Mexico these aspects are relevant according to the 2018 national financial inclusion survey conducted by the National Institute of Statistics and Geography (INEGI, 2018), in the Mexican banking sector there are 79.4 million potential consumers aged 18 to 70 years. Of which only 54 million (68\%) have a financial product, this figure has not increased since the 2015 survey.

The most recurring financial product is the bank account with 37.3 million consumers, followed by the credit with 24.6 million. Specifically, within the bank accounts section, the payroll account is the most representative with 22.5 million, which corresponds to $60 \%$ of the users of bank accounts (INEGI, 2018).

In relation to digital banking, only 11.8 million Mexicans indicated having used a digital banking service, in contrast 42.2 million Mexicans indicated using traditional banking, one of the main reasons was the preference of service such as window (INEGI, 2018). Therefore, it is important for the banking sector to identify which aspects of traditional banking services are considered most relevant by consumers when determining the perception of quality in products and services. Being fundamental in two senses, it will mainly serve to develop more efficient service strategies focused on stimulating consumers to integrate and stay within the banking sector.

Currently, there are several studies about the quality perception in the banking sector, for example, in the Middle East, there are the studies of Ali \& Raza (2015) in Pakistan, Ananda \& Sonal (2019) in Oman. In Europe, the study by Canals (2002) in Spain and in Latin America that of Carvajal, Leguina, \& Zamorano (2013) in Chile. In Mexico, the studies by Vera \& Trujillo (2018) and Vega et al. (2008). These studies on the quality perception in the banking sector have, for the most part, contributed with positive results to the academic literature. However, they have put aside the segmentation of banking, by considering the services of the banking sector in a global way, without making any distinction between traditional banking and digital banking.

This is found in most quality perception studies of the banking sector, which omits two essential aspects in this sector. The first one is not to separate traditional banking services from digital banking services. This is fundamental since modern banking is defined as a traditional and digital banking services union. In the case of investigations in Mexico, this omission will create a bias. The results of national inclusion surveys regarding the use of digital and traditional banking show approximately $80 \%$ of the consumers of banking services in Mexico use only traditional banking.

A generation is defined as a set of historical events and related phenomena that create a distinct generational difference (Parry \& Urwin, 2011). Every generation arises according to the date of birth, and they have a specific social behavior. Generation $\mathrm{Z}$ or centennials are defined as those people born between the years 1996 and 2007 (Oblinger, 2003). Most of the people belonging to genera- 
tion $\mathrm{Z}$ have used the internet from a very young age and are comfortable with technology and social networks. Generation $Z$ people are estimated to make up $23.7 \%$ of the world's population.

Also, most of the studies perform little stratification in relation to the consumer, in some cases excluding aspects such as life stage, income, consumption characteristics, socioeconomic status, among others. With this, limiting the understanding of quality perception of banking services in the various consumer segments that currently exist in the sector.

Therefore, before conducting a quality perception study in the banking sector, it is necessary to consider the different types of consumers in relation to life stages, income status and consumption characteristics. As well as its affinity with technology, which can be considered as a fundamental factor when referring to digital and traditional banking. Hence, this research seeks to quantify which aspects are more decisive in the Mexican Gen $Z$ consumers, when developing quality perception towards traditional banking services through the application of the SERVQUAL model proposed by Parasuraman, Zeithaml, \& Berry (1988). Additionally, this research will segment consumers based on aspects such as socioeconomic status and gender.

\section{Research Methodology}

\subsection{Type of Investigation}

The research methodology is cross-sectional according to the method used to retrieve the information, which was obtained through the application of a data collection instrument. The objective of the research is considered correlational-causal, by seeking the relationship between the variables. Therefore, this study is quantitative (Fernandez \& Hernandez, 2014).

\subsection{Object of Study}

The object of study for this research was defined based on the ICC/ESOMAR International Code of Market, Opinion and Social Research and Data Analysis. Particularly on article two subsection a \& b. Due to the method to collect data for this study, the established age ranges are between 18 and 24 years.

According to the 2010 census, carried out by the National Institute of Statistics and Geography (INEGI), in Mexico, generation Z corresponds to 27.4 million, $24.9 \%$ of the population in Mexico, where 10 million meet the age range for the study, being the state of Mexico and Mexico City (Valley of Mexico) entities that contribute the most population with 2.4 million in total.

Therefore, residents of the Valley of México (Mexico City and the State of Mexico) were defined as the object of study. With ages ranging between 18 and 24 years, without any distinction of gender and with the condition that during any time of their life have had or contracted a product or service of the banking sector. 


\subsection{Assessment Instrument}

To collect the information, the SERVQUAL instrument was adapted and applied as a survey containing 22 items. The instrument measured the quality perception of traditional banking services considering the variables: tangibility, reliability, responsiveness, assurance, and empathy. The measures for the variables were adopted from an existing 7 -point Likert-type scale $(1=$ Completely disagree, $7=$ Completely agree).

\subsection{Data Collection and Processing}

The sample size for the study was determined by using the sample size formula for a finite population (Equation (1)) (Triola, 2004), with a confidence status of $95 \%$, a margin of error of $5 \%$, with probability of success, $p$, of 0.5 , and a population of 2.4 million. Resulting in a sample size of $n=385$. The study data were collected through a survey applied in various regions of the Valley of Mexico during the first quarter of 2020 .

$$
n=\frac{N \times Z^{2} \times p \times q}{d^{2} \times(N-1)+Z^{2} \times p \times q}
$$

Equation (1). Sample size for a finite population. Where $N$ is the total size of population, $Z$ is the confidence status, $d$ the error, $p$ is the probability of success, $q$ the failure probability and $n$ the acceptable sample size.

Statistical reliability of the collected data was analyzed using a Cronbach's Alpha (Equation (2)). Subsequently, each one of the variables (tangibility, reliability, responsiveness, assurance, and empathy) was analyzed. Defining an $\alpha>$ 0.9 as a parameter of acceptance for the study (Domínguez-Lara \& Merino-Soto, 2015).

$$
\alpha=\frac{K}{K-1}\left[1-\frac{\sum S_{i}^{2}}{S_{T}^{2}}\right]
$$

Equation (2). Cronbach's Alpha. where $\alpha$ is Cronbach's alpha, $\sum S_{i}^{2}$ is the sum of the variances of each item, $S_{T}^{2}$ is the variance of the total and $K$ is the number of items.

To calculate the correlation between the variables, a multiple linear regression was used for each one of the study variables (Equation (3)). Additionally, as statistical support it was applied a Pearson's correlation coefficient (Equation (4)). The acceptance criteria established is $R^{2}>0.8$ for the multiple linear regression and $r>0.9$ for the Pearson's $r$ (Santabárbara, 2019).

$$
t=\frac{\sum\left(X_{i}-\bar{X}\right)\left(Y_{i}-\bar{Y}\right)}{\sqrt{\sum\left(X_{i}-\bar{X}\right)^{2} * \sum\left(Y_{i}-\bar{Y}\right)^{2}}}
$$

Equation (3). Linear regression correlation coefficient, where $t$ is Linear regression correlation coefficient, $X$ is the independent variable and $Y$ is the dependent variable. 


$$
r=\frac{s_{x y}}{s_{x} * s_{y}}
$$

Equation (4). Pearson's correlation coefficient. Where $r$ is Pearson's correlation, $S_{x}$ and $S_{y}$ are the standard deviation of $X$ and $Y$ respectively and $S_{x y}$ is the sample covariance.

Multicollinearity was calculated in the study variables to suppress errors in the calculation of linear regression. The multicollinearity was determined by using a Kendal's Tau (Equation (4)), with an acceptance parameter of $T_{b}>0.8$ (Laurencelle, 2009).

$$
T_{b}=\frac{P-Q}{\sqrt{\left(P+Q+X_{0}\right)\left(P+Q+Y_{0}\right)}}
$$

Equation (5). Where $T_{b}$ is Kendal $s$ Tau, $P$ is the number of concordant pairs, $Q$ is the number of discordant pairs, $X_{0}$ is number of pairs tied on the independent variable $X, Y_{0}$ is number of pairs tied on the independent variable.

\section{Theoretical Framework}

\subsection{Consumer Satisfaction}

The quality perception by the consumer of a service is essential for the success of organizations since aspects such as loyalty and behavior are based on consumer satisfaction (Kotler, 2016). On the other hand, consumer loyalty considers the influence of the environment as a behavior modifier (Oliver, 1999). In addition, the development of loyalty is a complex process that will depend to a large extent on the consumer's perceived quality.

Quality is to satisfy the expectations of the consumer in relation to the service provided (Zeithaml, 2001). Zelthaml also views leading companies as those that meet consumer expectations. Meanwhile, expectations are an appreciation or perception of what will happen in the future, in this case by the consumer about the service (Cosacov, 2007).

The gap between consumer expectations and the satisfaction generated by the product and/or service defines the perception of quality (Parasuraman, Zeithaml, \& Berry, 1988). The better the consumer's expectations are satisfied, a higher quality perception is generated about the products or services offered, originating purchase satisfaction on the part of the consumer (Oliver, 1980).

Convergence between digital and traditional banking services has made it difficult to properly identify which aspects the consumer considers relevant in digital and traditional banking services. Therefore, the priority for companies in the banking sector in Mexico should be to identify the perception of quality of traditional banking services since it is used by 30 million more users than digital banking.

\subsection{SERVQUAL Model}

To quantify quality perception, Parasuraman, Zeithaml, \& Berry (1988), propose 
the Service Quality or SERVQUAL model. The model considers quality perception as the difference between expectations and the service received. Later studies showed that it is not necessary to quantify expectations, since the perception of the service generates the perception of quality (Cronin \& Taylor, 1992).

According to the SERVQUAL model, the perception of quality is quantified based on five factors: tangibility, reliability, responsiveness, assurance, and empathy. In the traditional banking sector, these builders are considered as follows:

- Tangibility refers to the appearance of the personnel, facilities, and equipment of the bank branch.

- Reliability is defined as the bank's ability to provide proper service without errors within the bank branch.

- Responsiveness is established as the service attitude of the bank branch employees towards the customer for helping them meet their needs.

- Assurance is the technical capacity to provide confidence to the client by the employees of the bank branch and

- Empathy is understood as the personalized or individualized attention that the bank branch gives to the client during the provision of the service.

\subsection{Generations and Income in the Banking Sector}

Generations will share aspects such as age, life stages and will be linked by a generational perspective that originates shared behavior, criteria, and opinions. However, these will be completely different from the predecessor and subsequent generations (Ortega \& Gasset, 1933). Now, four generations can be classified in the banking sector: Baby Boomer (1947-1964), X (1965-1980), Y (1981-1995), and Z (>1995).

The Boom or Baby Boomers generation is a generation made up of the population born between 1947 and 1964 who are currently between 55 and 73 years old. Concerning consumption, they are a large segment of the population, and their main channel of consumption is physical (Oblinger \& Oblinger, 2005).

Generation X or Xers is a generation made up of the population born between 1965 and 1980. Currently, they are between 40 and 55 years old. Regarding the consumption of this generation, their main channel is physical. Despite being a generation with technological skills, they have a low status of online shopping and a great income capacity (Smola \& Sutton, 2002).

The NetGen generation, also known as Generation Y or Millennials, is a generation that is made up of the population born between 1981 and 1995 who are currently between the ages of 25 and 39. Regarding consumption, it is necessary to consider their great affinity with technology, their consumption channel is digital however, they can alternate with physical consumption (Seaton \& Boyd, 2007).

Finally, the Generation $\mathrm{Z}$ or Gen $\mathrm{Z}$ is a generation conformed by the population born between 1996 and 2010, currently between 11 and 25 years old (Torocsik, Szucs, \& Kehl, 2014). This generation can be referred to by other names 
like the Facebook generation (Prensky, 2001). They consider themselves technology experts for this reason the use of the internet is essential for them, they are used to getting answers immediately and their consumption is mainly by digital channels (Cassany \& Ayala, 2008).

Specifically, in Mexico during the next decade, generation $\mathrm{Z}$ will experience significant changes in their life stages and income structures. These modifications are characterized by two aspects; the first one is that the income and consumption of this generation will increase considerably and, the second is that these changes will be sustained over time for a long time.

In Mexico, the Mexican Association of Market Intelligence and Opinion Agencies (AMAI) determines eight socioeconomic statuses. Socioeconomic statuses are classified by average monthly household income; where A and B are high-income statuses corresponding to $6.6 \%$ of the population, $\mathrm{C}+$ and $\mathrm{C}$ are middle income being $26.5 \%, \mathrm{C}$ - and $\mathrm{D}+$ correspond to an average income with a $29.6 \%$ of the population, and finally $\mathrm{D}-$ and $\mathrm{E}$ are low-income corresponding to $37.3 \%$ (AMAI, 2018).

\section{Results}

\subsection{Reliability Analysis}

For the analysis 458 questionnaires were obtained, of which only 447 were filled correctly. The answers of non-residents of the Valley of Mexico, the ones that did not meet the age range, and those who had not purchased a product or service from the banking sector were excluded from the study, giving a total of 394 valid questionnaires, thus giving validity to the study. Regarding the demographic aspects of the respondents, about gender, the percentage of women was higher with $237(60.15 \%)$ compared to men with 157 (39.85\%). In addition, $1.02 \%$ reported belonging to socioeconomic status $\mathrm{A}, 3.81 \%$ indicated status $\mathrm{B}$, 9.64\% reported being part of status $\mathrm{C}+, 16.75 \%$ indicated status $\mathrm{C}, 20.81 \%$ reported being part of status C-, $25.13 \%$ part of status D+, $19.04 \%$ at status D and $3.81 \%$ status E (Table 1 ).

Before presenting the results of the structural model, the validity of the results for the 394 surveys was determined. Construct items: tangibility, reliability, responsiveness, assurance, and empathy were analyzed using a Cronbach's Alpha. Later, the full constructs were analyzed. The validity analysis of the items resulted in values higher than 0.900 in all cases. The results by construct showed values of 0.962 for tangibility, 0.949 for reliability, 0.941 for responsiveness, 0.943 for assurance, and 0.944 for empathy. These values suggest that both the items and the constructs for the study are valid (Table 2).

The multicollinearity analysis presented in Table 3 shows the assessment between tangibility, reliability, responsiveness, assurance, and empathy constructs. To identify collinearity that may affect the subsequent analysis. Tangibility construct showed values $0.455,0.475,0.450$, and 0.516 for reliability, responsiveness, 
Table 1. Demographic data.

\begin{tabular}{lcc}
\hline \multicolumn{1}{c}{ Indicator } & Factor & Percentage \\
\hline Global & 394 & $100 \%$ \\
\hline Socioeconomic status & & \\
A & 4 & $1.02 \%$ \\
B & 15 & $3.81 \%$ \\
C+ & 38 & $9.64 \%$ \\
C & 66 & $16.75 \%$ \\
C- & 82 & $20.81 \%$ \\
D+ & 99 & $25.13 \%$ \\
D & 75 & $19.04 \%$ \\
E & 15 & $3.81 \%$ \\
\hline Gender & & \\
Male & 237 & $60.15 \%$ \\
Female & 157 & $39.15 \%$ \\
\hline
\end{tabular}

Source: Own elaboration with data obtained from social science statistical package (SPSS) version 26.

Table 2. Evaluation instrument validation: Cronbach's Alpha results.

\begin{tabular}{|c|c|c|c|c|c|}
\hline & Construct/Item & Mean & Standard & Variance & $\begin{array}{l}\text { Cronbach's alpha } \\
\text { (if the item or variable }\end{array}$ \\
\hline \multirow{5}{*}{ 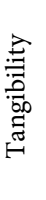 } & Tangibility & 5.2360 & 1.55726 & 2.425 & 0.962 \\
\hline & Item 1 & 4.9162 & 1.76641 & 3.120 & 0.970 \\
\hline & Item 2 & 5.0685 & 1.65555 & 2.741 & 0.969 \\
\hline & Item 3 & 5.3528 & 1.79479 & 3.221 & 0.969 \\
\hline & Item 4 & 5.2995 & 1.65824 & 2.750 & 0.969 \\
\hline \multirow{6}{*}{ 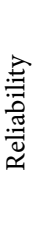 } & Reliability & 5.2284 & 1.61690 & 2.614 & 0.949 \\
\hline & Item 5 & 4.9340 & 1.82733 & 3.339 & 0.969 \\
\hline & Item 6 & 5.2411 & 1.81462 & 3.293 & 0.969 \\
\hline & Item 7 & 5.1599 & 1.92011 & 3.687 & 0.969 \\
\hline & Item 8 & 5.1827 & 1.67061 & 2.791 & 0.968 \\
\hline & Item 9 & 5.3985 & 1.76799 & 3.126 & 0.968 \\
\hline \multirow{5}{*}{ 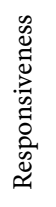 } & Responsiveness & 5.1726 & 1.39270 & 1.940 & 0.941 \\
\hline & Item 10 & 5.2766 & 1.5701 & 2.465 & 0.968 \\
\hline & Item 11 & 5.1954 & 1.76332 & 3.109 & 0.969 \\
\hline & Item 12 & 5.3274 & 1.53895 & 2.368 & 0.969 \\
\hline & Item 13 & 4.9569 & 1.68383 & 2.835 & 0.969 \\
\hline \multirow{5}{*}{ 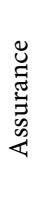 } & Assurance & 4.2259 & 1.32590 & 1.758 & 0.943 \\
\hline & Item 14 & 5.2183 & 1.72781 & 2.985 & 0.968 \\
\hline & Item 15 & 5.3299 & 1.65398 & 2.736 & 0.969 \\
\hline & Item 16 & 5.3046 & 1.91515 & 3.668 & 0.968 \\
\hline & Item 17 & 5.5939 & 1.67227 & 2.797 & 0.968 \\
\hline \multirow{6}{*}{ 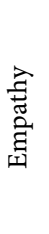 } & Empathy & 5.2919 & 1.37539 & 1.892 & 0.944 \\
\hline & Item 18 & 5.7081 & 1.58189 & 2.502 & 0.968 \\
\hline & Item 19 & 5.4569 & 1.86693 & 3.485 & 0.969 \\
\hline & Item 20 & 5.3223 & 1.41786 & 2.010 & 0.969 \\
\hline & Item 21 & 5.3046 & 1.43870 & 2.070 & 0.968 \\
\hline & Item 22 & 5.2665 & 1.43831 & 2.069 & 0.970 \\
\hline
\end{tabular}

Source: Own elaborating with data obtained from social science statistical package (SPSS) version 26. 
Table 3. Multicollinearity analysis.

\begin{tabular}{lccccc}
\hline & Tangibility & Reliability & Responsiveness & Assurance & Empathy \\
\hline Tangibility & 1 & & & & \\
Reliability & 0.455 & 1 & 1 & & \\
Responsiveness & 0.475 & 0.718 & 0.736 & 1 & \\
Assurance & 0.450 & 0.606 & 0.718 & 0.724 & 1 \\
Empathy & 0.516 & 0.590 & & & \\
\hline
\end{tabular}

Source: Own elaboration with data obtained from social science statistical package (SPSS) version 26.

assurance, and empathy, respectively. Reliability presented results of 0.718 , 0.606 , and 0.590 for responsiveness, assurance, and empathy, respectively.

Responsiveness results had values of 0.736 for assurance and 0.718 for empathy. In addition, assurance showed a value of 0.724 for the empathy construct. Among the most significant results, the responsiveness construct showed signs of collinearity with empathy, reliability, and assurance constructs. However, collinearity is not considered significant depending on the study parameters; therefore these values do not affect or be considered for multiple regression analyses.

\subsection{Variable Analysis}

Table 4 shows the results of the linear regression for tangibility construct where the general analysis presented values of 0.744 for Pearson's correlation and 0.554 for $R^{2}$. In addition, the socioeconomic status analysis showed indicators below 0.800 for all statuses. As well as the gender analysis that shows values lower than 0.800 with an $R^{2}$ of 0.541 for women and 0.553 for men.

Therefore, the results determine that the perception of the quality of the services of the traditional banking sector is not influenced by tangible aspects in these services, such as the presence of the staff, the image of the physical facilities, and the equipment of the branch.

Linear regression analysis results for the reliability variable are presented in Table 5, where values for $R^{2}$ and Pearson's correlation are 0.775 and 0.880 . On the other hand, the analyses by socioeconomic status showed accepted indicators at $\mathrm{C}+$ and $\mathrm{B}$ status with values of 0.822 and 0.890 for $R^{2}$ and 0.906 and 0.943 for Pearson's correlation, respectively.

Meanwhile, gender analyses present values of $R^{2} 0.798$ for women and 0.730 for men. These results indicate that reliability aspects like waiting time in the branch and the reduction of errors during the service, among others, do not have a significant connection in the quality perception of traditional banking services, except for specific statuses such as like B and C+.

Table 6 presents the results of the responsiveness analyses. For the general analysis, it shows an $R^{2}$ of 0.865 and a Pearson correlation of 0.930 . In addition, the analyzes by socioeconomic status showed an $R^{2}$ of $0.818,0.977,0.904,0.864,0.878$, $0.868,0.882$ and 0.827 for statuses $\mathrm{A}, \mathrm{B}, \mathrm{C}+, \mathrm{C}, \mathrm{C}-, \mathrm{D}+, \mathrm{D}$ and E, respectively. 
Table 4. Tangibility construct linear regression analysis results.

\begin{tabular}{lcccccc}
\hline Independent variable & Factor & $\begin{array}{c}\text { Not } \\
\text { standardized beta }\end{array}$ & $\begin{array}{c}\text { Standard error } \\
\text { coefficient }\end{array}$ & $\begin{array}{c}\text { Pearson's } \\
\text { correlation }\end{array}$ & $\boldsymbol{R}^{2}$ & $\begin{array}{c}\text { Correlation } \\
\text { verification }\end{array}$ \\
\hline Global & 394 & 0.651 & 0.030 & 0.744 & 0.554 & Rejected \\
\hline Socioeconomic Status & & & & & & \\
A & 4 & -1.000 & 0.433 & 0.853 & 0.727 & Rejected \\
B & 15 & 0.729 & 0.092 & 0.853 & 0.728 & Rejected \\
C+ & 38 & 0.666 & 0.062 & 0.872 & 0.761 & Rejected \\
C & 66 & 0.747 & 0.068 & 0.808 & 0.653 & Rejected \\
C- & 82 & 0.668 & 0.085 & 0.660 & 0.436 & Rejected \\
D+ & 99 & 0.663 & 0.065 & 0.710 & 0.517 & Rejected \\
D & 75 & 0.665 & 0.072 & 0.734 & 0.539 & Rejected \\
E & 15 & 0.654 & 0.141 & 0.789 & 0.622 & Rejected \\
\hline Gender & & & & & & Rejected \\
Female & 237 & 0.635 & 0.038 & 0.735 & 0.541 & Rejected \\
Male & 157 & 0.661 & 0.048 & 0.744 & 0.553 & \\
\hline
\end{tabular}

Note: Quality perception is the dependent variable. Source: own elaboration.

Table 5. Linear regression analysis results of the reliability construct.

\begin{tabular}{|c|c|c|c|c|c|c|}
\hline Independent variable & Factor & $\begin{array}{c}\text { Not } \\
\text { standardized beta }\end{array}$ & $\begin{array}{l}\text { Standard error } \\
\text { coefficient }\end{array}$ & $\begin{array}{l}\text { Pearson's } \\
\text { correlation }\end{array}$ & $R^{2}$ & $\begin{array}{l}\text { Correlation } \\
\text { verification }\end{array}$ \\
\hline Global & 394 & 0.742 & 0.020 & 0.880 & 0.775 & Rejected \\
\hline \multicolumn{7}{|l|}{ Socioeconomic Status } \\
\hline A & 4 & 0.636 & 0.545 & 0.636 & 0.405 & Rejected \\
\hline B & 15 & 0.846 & 0.083 & 0.943 & 0.890 & Accepted \\
\hline $\mathrm{C}+$ & 38 & 0.727 & 0.056 & 0.906 & 0.822 & Accepted \\
\hline $\mathrm{C}$ & 66 & 0.688 & 0.045 & 0.888 & 0.789 & Rejected \\
\hline $\mathrm{C}-$ & 82 & 0.685 & 0.043 & 0.873 & 0.763 & Rejected \\
\hline $\mathrm{D}+$ & 99 & 0.740 & 0.044 & 0.861 & 0.741 & Rejected \\
\hline $\mathrm{D}$ & 75 & 0.836 & 0.047 & 0.901 & 0.812 & Rejected \\
\hline $\mathrm{E}$ & 15 & 0.878 & 0.153 & 0.847 & 0.718 & Rejected \\
\hline \multicolumn{7}{|l|}{ Gender } \\
\hline Female & 237 & 0.761 & 0.025 & 0.893 & 0.798 & Rejected \\
\hline Male & 157 & 0.690 & 0.034 & 0.854 & 0.730 & Rejected \\
\hline
\end{tabular}

Note: Quality perception is the dependent variable. Source: own elaboration.

The analyses by gender set values for women of $R^{2}=0.840$ and Pearson's correlation $=0.916$ and for men of $R^{2}=0.905$ and Pearson's correlation $=0.951$. The results indicate that aspects of responsiveness, such as employee-user communication, the attitude of service, and customer service, among others, contribute to defining the quality perception in traditional banking services.

The results of the assurance variable are presented in Table 7, which contains values of 0.816 for $R^{2}$ and 0.903 for Pearson's correlation in global analysis. On the other hand, the analyses by socioeconomic status indicated acceptable parameters for the research at statuses A $\left(R^{2}=0.816\right.$, Pearson's correlation $\left.=0.903\right)$, $\mathrm{B}\left(R^{2}=0.905\right.$, Pearson's correlation $\left.=0.951\right), \mathrm{C}+\left(R^{2}=0.905\right.$, Pearson's correlation $=0.951)$ and $\mathrm{C}\left(R^{2}=0.905\right.$, Pearson's correlation $\left.=0.951\right)$. 
Table 6. Responsiveness construct linear regression analysis results.

\begin{tabular}{|c|c|c|c|c|c|c|}
\hline Independent variable & Factor & $\begin{array}{c}\text { Not } \\
\text { standardized beta }\end{array}$ & $\begin{array}{l}\text { Standard error } \\
\text { coefficient }\end{array}$ & $\begin{array}{l}\text { Pearson's } \\
\text { correlation }\end{array}$ & $R^{2}$ & $\begin{array}{l}\text { Correlation } \\
\text { verification }\end{array}$ \\
\hline Global & 394 & 0.910 & 0.018 & 0.930 & 0.865 & Accepted \\
\hline \multicolumn{7}{|l|}{ Socioeconomic Status } \\
\hline $\mathrm{A}$ & 4 & 0.500 & 0.167 & 0.905 & 0.818 & Accepted \\
\hline B & 15 & 1.003 & 0.042 & 0.989 & 0.977 & Accepted \\
\hline $\mathrm{C}+$ & 38 & 0.916 & 0.050 & 0.951 & 0.904 & Accepted \\
\hline $\mathrm{C}$ & 66 & 0.922 & 0.046 & 0.930 & 0.864 & Accepted \\
\hline $\mathrm{C}-$ & 82 & 0.894 & 0.053 & 0.937 & 0.878 & Accepted \\
\hline $\mathrm{D}+$ & 99 & 0.942 & 0.037 & 0.932 & 0.868 & Accepted \\
\hline $\mathrm{D}$ & 75 & 0.872 & 0.037 & 0.939 & 0.882 & Accepted \\
\hline $\mathrm{E}$ & 15 & 1.013 & 0.129 & 0.909 & 0.827 & Accepted \\
\hline \multicolumn{7}{|l|}{ Gender } \\
\hline Female & 237 & 0.895 & 0.026 & 0.916 & 0.840 & Accepted \\
\hline Male & 157 & 0.932 & 0.024 & 0.951 & 0.905 & Accepted \\
\hline
\end{tabular}

Note: Quality perception is the dependent variable. Source: self-made.

Table 7. Assurance construct linear regression analysis results.

\begin{tabular}{lcccccc}
\hline Independent variable & Factor & $\begin{array}{c}\text { Not } \\
\text { standardized beta }\end{array}$ & $\begin{array}{c}\text { Standard error } \\
\text { coefficient }\end{array}$ & $\begin{array}{c}\text { Pearson's } \\
\text { correlation }\end{array}$ & $\boldsymbol{R}^{2}$ & $\begin{array}{c}\text { Correlation } \\
\text { verification }\end{array}$ \\
\hline Global & 394 & 0.929 & 0.022 & 0.903 & 0.816 & Accepted \\
\hline $\begin{array}{l}\text { Socioeconomic Status } \\
\text { A }\end{array}$ & & & & & \\
B & 15 & 0.630 & 0.074 & 0.986 & 0.973 & Accepted \\
C+ & 0.976 & 0.041 & 0.989 & 0.978 & Accepted \\
C & 38 & 0.954 & 0.047 & 0.959 & 0.920 & Accepted \\
C- & 66 & 0.982 & 0.052 & 0.921 & 0.848 & Accepted \\
D+ & 82 & 0.815 & 0.056 & 0.850 & 0.723 & Rejected \\
D & 99 & 0.986 & 0.051 & 0.893 & 0.797 & Rejected \\
E & 75 & 0.890 & 0.057 & 0.876 & 0.767 & Rejected \\
\hline Gender & 15 & 1.065 & 0.068 & 0.865 & 0.749 & Rejected \\
Female & & & & & Rejected \\
Male & 237 & 0.947 & 0.031 & 0.895 & 0.799 & Accepted \\
\hline
\end{tabular}

Note: Quality perception is the dependent variable. Source: self-made.

Gender results showed indicators for men of $R^{2}=0.905$ and Pearson's correlation $=0.951$ and for women of $R^{2}=0.799$ and Pearson's correlation $=0.841$. These results determine that at status $\mathrm{A}, \mathrm{B}+, \mathrm{C}+$, and $\mathrm{C}$, aspects like the confidence in the correct execution of transactions within the branch, the amiability of the staff towards the clients, and the knowledge of the employees, among other aspects influence the quality perception of traditional banking services. Likewise, concerning gender, this influence is only valid for men.

Table 8 presents the results of the empathy analyzes, which indicated an $\mathrm{R}^{2}$ of 0.801 and a Pearson's correlation of 0.894 . Regarding socioeconomic status analyzes, the most representative values were found at status A $\left(R^{2}=0.827\right.$ Pearson's correlation $=0.909), \mathrm{B}\left(R^{2}=0.958\right.$ Pearson's correlation $\left.=0.979\right), \mathrm{C}+\left(R^{2}=0.878\right.$ Pearson's correlation $=0.937)$ and C $\left(R^{2}=0.958\right.$ Pearson's correlation $\left.=0.979\right)$. 
Table 8. Linear regression analysis results of the empathy construct.

\begin{tabular}{lcccccc}
\hline Independent variable & Factor & $\begin{array}{c}\text { Not } \\
\text { standardized beta }\end{array}$ & $\begin{array}{c}\text { Standard error } \\
\text { coefficient }\end{array}$ & $\begin{array}{c}\text { Pearson's } \\
\text { correlation }\end{array}$ & $R^{2}$ & $\begin{array}{c}\text { Correlation } \\
\text { verification }\end{array}$ \\
\hline Global & 394 & 0.886 & 0.022 & 0.894 & 0.801 & Accepted \\
\hline Socioeconomic Status & & & & & & \\
A & 4 & 1.000 & 0.433 & 0.909 & 0.827 & Accepted \\
B & 15 & 1.010 & 0.059 & 0.979 & 0.958 & Accepted \\
C+ & 38 & 0.870 & 0.054 & 0.937 & 0.878 & Accepted \\
C & 66 & 0.937 & 0.050 & 0.918 & 0.844 & Accepted \\
C- & 82 & 0.833 & 0.058 & 0.850 & 0.722 & Rejected \\
D+ & 99 & 0.856 & 0.053 & 0.855 & 0.731 & Rejected \\
D & 75 & 0.889 & 0.052 & 0.893 & 0.797 & Rejected \\
E & 15 & 0.976 & 0.079 & 0.960 & 0.921 & Rejected \\
\hline Gender & & & & & & Accepted \\
Female & 237 & 0.862 & 0.027 & 0.902 & 0.814 & Rejected \\
Male & 157 & 0.943 & 0.043 & 0.870 & 0.757 & \\
\hline
\end{tabular}

Note: Quality perception is the dependent variable. Source: self-made.

In turn, the analyses by gender showed results for women of $R^{2}=0.814$ Pearson's correlation $=0.902$ and for men $R^{2}=0.757$, Pearson's correlation $=0.870$. These results indicate that empathy aspects in traditional banking services such as personal attention and the understanding of customer needs, among others, influence the creation of quality perception in socioeconomic status $\mathrm{A}, \mathrm{B}, \mathrm{C}+$, and $\mathrm{C}$, in women.

\section{Discussion}

The results of the variables tangibility and reliability revealed that aspects such as the presence of the branch staff, the image of the physical facilities, a low status of error during service, or an adequate waiting time, are not relevant factors for the quality perception of Gen $\mathrm{Z}$ when receiving any traditional banking service.

This can be explained according to the postulation by Castellano and González (2010), who indicate that quality perception in service will be defined based on the received treatment. Therefore, the attitudes and behavior of employees of bank branches will have a greater influence on the consumer's quality perception than aspects such as waiting times or physical facilities.

On the other hand, the variables assurance, reliability, and empathy are considered transcendental when determining quality perception. Indeed, this is correct from the stand of Aparecida, Lopes and Oliveira (2015) who postulate that the quality of services will be considered according to the behavior, attitudes, and skills of the service providers, which are the in employees of the bank branch.

Regarding gender analysis results, it is demonstrated that women's quality perceptions are determined by responsiveness and empathy variables. In contrast, men's perception of quality is defined by responsiveness and assurance variables. 
In addition, socioeconomic analyzes had significant differences between the highest statuses (A, B, C+, and C) and the lowest (C-, D, D- and E). This difference can be observed in the variable's responsiveness, assurance, and empathy which are decisive in the perception of the quality of the higher statuses. Additionally, the reliability variable is important for status B and C+ and tangibility for B (Table 9).

On the contrary, at the lowest status (C-, D, D- and E), the quality perception of traditional banking services is determined solely by the responsiveness variable. The results indicate a preference on Mexican consumers for a service that favors employee-consumer interaction, due to the fact that the responsiveness variable is representative of all statuses.

The results of this study reaffirm the national financial survey outcomes that show that $80 \%$ of Mexican consumers in the banking sector prefer traditional banking to digital banking. According to the results, the preference for traditional banking is due to the ease of communication with the bank branch staff. As well as the service attitude that is more representative in this type of service.

In addition, it must be emphasized that $70 \%$ of the population in Mexico belongs to socioeconomic status $\mathrm{C}-, \mathrm{D}, \mathrm{D}-$ and $\mathrm{E}$, which determine their perception of quality by the responsiveness aspects, reinforcing the importance of the attitude of the employees, as well as the communication channels with staff.

The results from the perspective of Flint, Lusch and Vargo (2014) demonstrate that generation $\mathrm{Z}$ consumers, despite of requesting or favoring traditional banking services, have evolved from a view on the product to one on services. As demonstrated in this study, tangibility and reliability aspects come in second, giving greater relevance to aspects like responsiveness, assurance, and empathy which focus on employee-consumer interaction.

To sum up, the stagnation of consumer migration from traditional banking to digital banking is the reason consumers favor responsiveness aspects such as a

Table 9. Hypothesis comprobation by segment.

\begin{tabular}{cccccc}
\hline Independent variable & Tangibility & Reliability & Responsiveness & Assurance & Empathy \\
\hline Global & $\mathrm{X}$ & $\mathrm{X}$ & $\mathrm{O}$ & $\mathrm{O}$ & $\mathrm{O}$ \\
\hline Socioeconomic Status & & & & & \\
A & $\mathrm{X}$ & $\mathrm{X}$ & $\mathrm{O}$ & $\mathrm{O}$ & $\mathrm{O}$ \\
B & $\mathrm{O}$ & $\mathrm{O}$ & $\mathrm{O}$ & $\mathrm{O}$ & $\mathrm{O}$ \\
C+ & $\mathrm{X}$ & $\mathrm{O}$ & $\mathrm{O}$ & $\mathrm{O}$ & $\mathrm{O}$ \\
C & $\mathrm{X}$ & $\mathrm{X}$ & $\mathrm{O}$ & $\mathrm{O}$ & $\mathrm{O}$ \\
C- & $\mathrm{X}$ & $\mathrm{X}$ & $\mathrm{O}$ & $\mathrm{X}$ & $\mathrm{X}$ \\
D+ & $\mathrm{X}$ & $\mathrm{X}$ & $\mathrm{O}$ & $\mathrm{X}$ & $\mathrm{X}$ \\
D & $\mathrm{X}$ & $\mathrm{X}$ & $\mathrm{O}$ & $\mathrm{X}$ & $\mathrm{X}$ \\
E & $\mathrm{X}$ & $\mathrm{X}$ & $\mathrm{O}$ & $\mathrm{X}$ & $\mathrm{X}$ \\
\hline Gender & & & & & \\
Female & $\mathrm{X}$ & $\mathrm{X}$ & $\mathrm{O}$ & $\mathrm{X}$ & $\mathrm{O}$ \\
Male & $\mathrm{X}$ & $\mathrm{X}$ & $\mathrm{O}$ & $\mathrm{O}$ & $\mathrm{X}$ \\
\hline
\end{tabular}

Note: Where $\mathrm{O}$ is the accepted hypothesis and $\mathrm{X}$ the rejected hypothesis. 
good attitude of service and ease of communication between the consumer and the employee, which is more present in traditional services.

\section{Conclusion}

The restructuring of the Mexican financial system has maximized consumer importance as the center of the system. In fact, in the banking sector, the introduction of technology has helped develop several types of services focused on consumers. These can be classified into digital and traditional services. As shown by the 2018 financial inclusion survey, $80 \%$ of Mexican consumers prefer to use traditional banking services over digital.

This trend is worrying, given that the banking sector as well as other sectors is migrating towards digital features. Therefore, the design of strategies focused on the migration of the consumer from traditional to digital services is essential in the banking sector. Since the population of Generation $\mathrm{Z}$ is the priority. Because, during the next decade, they will be the main axis of consumption in Mexico with $24.9 \%$ of the population, as well as their affinity to technology.

Therefore, this study is relevant since it defined the elements generation $\mathrm{Z}$ favors in traditional banking services, by determining significant variables in the quality perception of traditional banking services, adding segmentation according to their socioeconomic status and gender.

Among the most important findings is the responsiveness variable which considers the attitude of the branch staff and communication with the staff, among others. This variable is present in all socioeconomic statuses, explaining with it the preference for traditional services. While these aspects of communication are not found in digital services.

Likewise, a difference was identified between the highest socioeconomic statuses $\mathrm{A}, \mathrm{B}, \mathrm{C}+\mathrm{C}$ which considers 3 to 5 variables when defining their quality perception. In contrast, $\mathrm{C}-, \mathrm{D}+, \mathrm{D}$ and $\mathrm{E}$ statuses only consider responsiveness as a variable in the quality perception.

To the academy, this study contributes to the current literature by the segmentation of traditional and digital banking in quality perception studies in the banking sector, providing more precise results based on the relevant variables for the consumer. Additionally, this study presents empirical evidence of the quality perception in Mexico by Generation Z, a topic less studied in the literature.

This research will work as a guide to the banking sector when developing strategies for generation $\mathrm{Z}$ in different socioeconomic statuses, mainly, in strategies focused on the migration of consumers towards digital banking services. Moreover, it will help the design of strategies aimed at attracting generation $\mathrm{Z}$ consumers. In addition, the results besides being positive, offer information on a little-explored approach in the banking sector.

In conclusion, the knowledge of this information will make it easier for the banking sector to plan the development of strategies that stimulate migration to 
digital banking services. By offering an understanding of which aspects of traditional banking services are considered relevant by the consumer and being able to emulate them within digital banking services.

\section{Acknowledgements}

This work was supported by UNAM-PAPIME <PE308920>. Investigación realizada gracias al Programa UNAM-PAPIME $<$ PE308920 $>$.

\section{Conflicts of Interest}

The authors declare no conflicts of interest regarding the publication of this paper.

\section{References}

Ali, M., \& Raza, S. A. (2015). Service Quality Perception and Customer Satisfaction in Islamic Banks of Pakistan: The Modified SERVQUAL Model. Total Quality Management \& Business Excellence, 28, 559-577. https://doi.org/10.1080/14783363.2015.1100517

AMAI (January 2018). Asociación Mexicana de Agencias de Inteligencia de Mercado y Opinión. https://www.amai.org/descargas/REVISION AMAI 2018 v2.pdf

Ananda, S., \& Sonal, D. (2019). Service Quality Dimensions and Customer Satisfaction: Empirical Evidence from Retail Banking Sector in Oman. Total Quality Management \& Business Excellence, 30, 1616-1629. https://doi.org/10.1080/14783363.2017.1393330

Aparecida, M., Lopes, R., \& Oliveira, B. (2015). Avaliac ,ão da qualidade de servic ,os terceirizados de intervenc ão emmobiliário e no layout em uma organizac ão pública. Revista de Administra,cão da Universidade Federal de SantaMaria, 8, 103-124.

Canals, C. S. (2002). Medida de la Calidad: Adaptación de la Escala Servqual al Ámbito Financiero. Spanish Journal of Finance and Accounting, 31, 803-831. https://doi.org/10.1080/02102412.2002.10779462

Carvajal, S. A., Leguina, A., \& Zamorano, P. E. (2013). Factores determinantes en la percepción de la imagen y calidad de servicio y sus efectos en la satisfacción del cliente: Un caso aplicado a la banca chilena. Revista de Ciencias Sociales, 19, 255-267. https://doi.org/10.31876/rcs.v19i2.25621

Casilda, R. (1997). Realidades y alternativas, el futuro de la banca. La banca virtual Esic-Market, 95, 53-62.

Cassany, D., \& Ayala, G. (2008). Nativos e inmigrantes digitales en la escuela. CEE, Participación Educativa, 9, 53-71. http://goo.gl/VSFlg1

Castellano, S., \& González, P. (2010). Calidad de servicio en farmacias tradicionales y de autoservicio: Estudio de caso. Revista Venezolana de Gerencia, 15, 570-590. https://doi.org/10.31876/revista.v15i52.10587

Cosacov, E. (2007). Diccionario de Términos Técnicos de Psicología (3ra Ed.). Brujas.

Cronin, J. J., \& Taylor, S. A. (1992). Measuring Service Quality: A Reexamination and Extension. Journal of Marketing, 56, 55-68. https://doi.org/10.1177/002224299205600304

Domínguez-Lara, S., \& Merino-Soto, C. (2015). Por qué es importante reportar los intervalos de confianza del coeficiente alfa de Cronbach? Revista Latinoamericana de Ciencias Sociales, Niñez y Juventud, 13, 1326-1328. 
Fernandez, C., \& Hernandez, R. (2014). Metodología de la Investigación. McGraw-Hill.

Flint, D., Lusch, R., \& Vargo, S. (2014). The Supply Chain Management of Shopper Marketing as Viewed through a Service Ecosystem Lens. International Journal of Physical Distribution and Logistics Management, 44, 23-38. https://doi.org/10.1108/IJPDLM-12-2012-0350

INEGI (23 de noviembre de 2018). Tercera encuesta nacional de inclusión financiera. https://www.inegi.org.mx/contenidos/saladeprensa/boletines/2018/OtrTemEcon/ENIF 2018.pdf

Kotler, P. (2016). Dirección de Marketing. Pearson Educación.

Laurencelle, L. (2009). Le tau et le tau-b de Kendall pour la corrélation de variables ordinales simples ou catégorielles. Tutorials in Quantitative Methods for Psychology, 5, 51-58. https://doi.org/10.20982/tqmp.05.2.p051

Márquez, A. (2000). Internet y la actividad bancaria. Papeles de Economía Española, 84-85, 330-339.

Oblinger, D. G. (2003). Boomers, Gen-Xers, and Millennials: Understanding the "New Students". EDUCAUSE Review, 38, 36-45.

Oblinger, D., \& Oblinger, J (2005). Educating the Net Generation. Educause.

Oliver, R. L. (1980). A Cognitive Model of the Antecedents and Consequences of Satisfaction Decisions. Journal of Marketing Research, 17, 460-469. https://doi.org/10.1177/002224378001700405

Oliver, R. L. (1999). Whence Consumer Loyalty? Journal of Marketing, 63, 33-44. https://doi.org/10.2307/1252099

Ortega, \& Gasset, J. (1933). El método histórico de las generaciones. En torno a Galileo, Obras completas. Revista de Occidente [1947].

Parasuraman, A., Zeithaml, V., \& Berry, L. (1988). Servqual: A Multiple-Item Scale for Measuring Consumer Perception If Service Quality. Journal of Retailing, 64, 12-40.

Parry, E., \& Urwin, P. (2011). Generational Differences in Work Values: A Review of Theory and Evidence. International Journal of Management Reviews, 13, 79-96. https://doi.org/10.1111/j.1468-2370.2010.00285.x

Prensky, M. (2001). Digital Natives, Digital Immigrants. On the Horizon, 9, 1-6. https://doi.org/10.1108/10748120110424816

Rexha, N., John, R. P., \& Shang, A. S. (2003). The Impact of the Relational Plan on Adoption of Electric Banking. Journal of Services Marketing, 17, 53-67.

https://doi.org/10.1108/08876040310461273

Santabárbara, J. (2019). Cálculo del intervalo de confianza para los coeficientes de correlación mediante sintaxis en SPSS. Revista d'Innovació i Recerca en Educació, 12, 1-14. https://doi.org/10.1344/reire2019.12.228245

Seaton, L. J., \& Boyd, M. (2007). The Organizational Leadership of the Post Baby Boom Generation: An Upper Echelon Theory Approach. Academy of Entrepreneurship Journal, 13, 69-77.

Smola, K., \& Sutton, C. D. (2002). Generational Differences: Revisiting Generational Work Values for the New Millennium. Journal of Organizational Behavior, 23, 363-382. https://doi.org/10.1002/job.147

Torocsik, M. Szucs, K., \& Kehl, D. (2014). How Generations Think: Research on Generation Z. Acta Universitatis Sapientiae, Communicatio, 1, 23-45.

Torres, E., \& Vásquez-Párraga, A. Z. (2005). Integrando los Beneficios para el Cliente 
de Servicios Bancarios: Banca Tradicional Versus Banca en Internet. Panorama Socioeconómico, 23, 8-21.

Triola, M. (2004). Estimados y tamaño de muestra. In M. Triola (Ed.), Estadística (pp. 318-357). Pearson Educación.

Vega, R., Fonseca, I., Cadena, M., \& Rivera, C. (2008). Analizando la calidad de los servicios bancarios en la ciudad de Caborca, Sonora, México. EPISTEMUS. Ciencia, Tecnología y Salud, 5, 15-22

Vera, J., \& Trujillo, A. (2018). Medir desempeño del servicio de bancos detallistas en México: Una adaptación del Servperf. Contaduría y administración, 63, 1-17. https://doi.org/10.22201/fca.24488410e.2018.1106

Villafani-Ibarnegaray, M., \& González, V. C. (01 de julio de 2006). El sector bancario y las finanzas populares mexicanas: Retos, oportunidades y amenazas para las organizaciones de microfinanzas. https://bit.ly/3ELJGeZ

World Bank (5 de septiembre de 2020). Sector financiero. https://www.bancomundial.org/es/topic/financialsector/overview\#1

Zeithaml, A. (2001). Marketing de servicios un enfoque de integración del cliente a la empresa. McGraw Hill. 